\title{
The Form of Culture in Parébhâsan (a Genre of Oral Literature) Madura
}

\author{
M T Supratman, Rahmad and Y Linarsih \\ Indonesian Language Education Departement \\ Universitas Madura, Pamekasan, Indonesia \\ *Corresponding author email: tauhed@unira.ac.id
}

\begin{abstract}
Parébhâsan Madura as a genre of oral literature in Madura contains various values of life that are still actual with the spirit of the times, especially the Madurese community. Parébhâsan Madura as a result of folk literature, in fact contains certain values that need to be preserved and imitated by today's young generation. This research is a qualitative research. The method used in this research is descriptive method. The description method is a method that describes or describes facts or symptoms systematically about religious, philosophical, and ethical values in the parébhâsan Madura. The data collection technique is done by using documentation technique. The results showed that in Parébhâsan Madura there were 1) forms of religious values; 2) forms of philosophical values; 3 ) forms of ethical values
\end{abstract}

Keywords: religious, philosophical, and ethical values, parébhâsan Madura

\section{INTRODUCTION}

Madurese humans, in this case Madurese ancestors, are good at using the natural environment as a source for the creation of sani (read: literature), even Madurese humans themselves, so it can also be said that the local culture of Madura originates from nature and humans[1]. One of the local wisdoms of Madura is par Liberation. It turns out that the Madurese proverb is meant to act as a guide for character and behavior. His wisdom and wisdom, the old Madurese elders and intellectuals apparently observed the many traits and behaviors of Madurese people that did not fulfill the desired ideotype. To put it straight, hundreds of proverbs were issued and created[2].

Parébhâsan is one of the oral literature of the Madurese ancestral heritage which contains Madurese local culture and wisdom. The Madurese parébhâsan and saloka books are a collection of arebas and saloka that exist and are used as parébhâsan Madurese culture[3].

Parébhâsan and Saloka Madura are books that were born out of Oemar Sastrodiwirjo's concern because of these parébhâsan and saloka in the last four decades many Madurese people are not familiar with (and do not) know the proverbs and verse in the form of ancestral wisdom. As a result, the glorious teachings that were passed down were no longer known. In 1979, Sastrodiwirjo succeeded in collecting 1644 proverbs and verses. The wisdom of parébhâsan and seloka contains an attitude of life and is an ideal form of Madurese culture from the past Madurese[3]

The form of Madurese culture is a form of fundamental complexity in the belief patterns of behavior, thoughts and attitudes that are learned by a group of Madurese people and passed down to the next generation[4].

\subsection{Religious Values in Madura Culture}

Religious value is a religious value, namely belief in God. Religious values in Madurese culture are: (1) recognition of the oneness of God, (2) recognition that God is Almighty, (3) recognition of fate and destiny in human life, (4) surrender to Allah, (5) confession of love high to Allah, and (6) kiai or ulama are positioned as a figure close to Allah[5][6]

\subsection{Forms of Philosophical Values in Madura Culture}

The form of philosophical values in Madurese culture can be seen from the viewpoint of the Madurese society in seeing life, such as: (1) According to the Madurese view, life is a struggle, (2) in seeing the nature of life, the Madurese view that humans are basically good, they are born a holy state (fitrah), it can be good or bad depending on the environment, especially parents, family and society, especially the individual himself. (3) the Madurese view of the nature of time, the Madurese know the concept of time that is oriented to the past, present, and future. (4) the view of the Madurese community regarding the nature of the relationship between the 
Madurese community and their fellowmen, is conceptualized in the form of social stratification (bhapa ', bhabhu', ghuru, rato), cooperation (royongan), knight attitudes (ango'an poteya tolang e tembhang pote mata), attitude of an officer (bulang Ling Tuhu Warsito), and honest (jhujhur / ghate / ta 'anduri pandan) [5], [6]

\subsection{Forms of Ethical Values in Madura Culture}

The form of ethical values in Madurese culture are: (1) ethics towards God, namely by always praising and chanting the name of Allah, carrying out orders and staying away from prohibitions, (2) ethics towards nature, namely processing nature and all its contents, without destroying nature, (3) ethics towards others, namely humility and respect for others[5], [6].

\section{METHOD}

The approach used in this study is a qualitative approach. This study aims to examine and find out more about the forms of religious values, forms of philosophical values, and forms of ethical values of Madurese culture in the Madurese par Liberation. This research is described using a qualitative description research design. Qualitative research makes use of interpretive methods by presenting them in the form of descriptions. The qualitative description method is a method that is descriptive in the sense that the analyzed data and the results are in the form of descriptions of phenomena and not in the form of numbers so that the data collected is in the form of words.

Miles and Huberman suggest that what is contained in qualitative research is data that appears in the form of words and not a series of numbers. The data may have been collected in a variety of ways (observation, interviews, document digest, tapes), and is usually "processed" approximately before it is ready for use (through note-taking, typing, editing, or writing), but qualitative analysis remains. using words, which are usually organized into extended text.[7]

\section{RESULTS}

\subsection{Religious Values in Madura Culture}

The Madurese community is known as a religious society. The majority of the population of Madura is Muslim. A religious society is, of course, a society that likes mutual cooperation and solidarity. Get along well with neighbors, friends, and relatives is a custom of the Madurese community.
We can see a religious society from the habits of the Madurese people who help each other to help and help others. Helping each other, helping each other, or mutual cooperation, will make the Madurese community equally safe. Mara alas bân macan, one of the Madurese par Liberation which is an oral literature from the Madurese past which reflects the religiosity of the Madurese people.

Beccè 'atèna means bhâghus atèna, lèbur atolong[3]. Kind, happy to help. The parébhâsan shows the religious attitude of the Madurese community, namely the sling of help. Please help show that the Madurese community is a harmonious society that is able to tolerate others.

Parébhâsan appealed to fellow humans to help each other in all matters of goodness. Helping or helping each other makes the heart calmer because there will be no enmity so that we are both safe in the world and will also bring salvation to the hereafter.

Mutual help is a reflection of the solidarity that exists in Madurese society. The compactness of the Madurese community is also influenced by their leaders. The tadâ 'alas ta' bâdâ macann[3] parébhâsan has the meaning of è tong-settongnga kennengngan mastè bâdâ wa-towa sè è èkatodusi. Parébhâsan revealed that in every place there must be a respected leader. The Madurese community is a religious society. This is evident in one of the many Islamic boarding schools and the number of madrasas available. The Madurese community has leaders from among the kiyai or ulama.

Madurese clerics and scholars are leaders who are respected by the Madurese community. One of the reasons may also be that the Madurese are adherents of Islam and highly uphold values based on Islam. The cleric or ulama may be considered a figure who is suitable to be a leader considering the knowledge of his religion which is considered qualified so that it can govern society, can guide society, and protect society, and lead people to a better life not only in the world but also in the hereafter.

The strong religiosity of the Madurese community is also reflected in the parébhâsan ngabbherrâ ta 'tèngghi, akoro'a ta' dâlem[3] which means ta 'andi' kakobâsaan which is equally sakalè which when translated into Indonesian, it has no power at all. The parébhâsan shows the humility of the Madurese who realizes that he is nothing in himself.

Being humble also shows religiosity, which means that the Madurese are people who are good at being grateful and aware of their own shortcomings 
or inadequacies, but with this awareness it also means that the Madurese people want to improve themselves to become better individuals.

Realizing that their inability to "have no power at all" makes the Madurese people become strong and resolute in facing life's problems.

\subsection{Philosophical Values in Madura Culture}

The philosophical values in Madurese culture can be seen from the perspective of the Madurese people in seeing life. One of the Madurese views of life can be seen from Parébhâsan "ta 'kakorangan akal"[3] (many ways of solving problems) which means masté nemmo jhâlân kalowar (there must be a way to solve problems). Masté nemmo jhâlân kalowar or if it is interpreted definitely getting a way out is one of the freedoms that can be used as a view of life which is also worthy of emulation.

Facing a big problem does not seem to be a significant obstacle considering the Madurese people have a good and wise view of life. Every problem can be dealt with properly because the Madurese have positive thoughts, namely that they must get a solution.

We can get a way out if we have a clear mind. Dealing with every problem will feel much easier and you can get peace. Not taking the problem too seriously, but also not underestimating the problems that occur to get a solution is a wise way of life in order to find a way out.

Always thinking clearly and wisely in getting solutions to problems is one of the worldviews that we must emulate. Being humble and always being wise are also very important to be able to interact well with the surrounding community. One of the ideals that we can use as a way of life that we should exemplify from the Madurese community is saarèp dhâddhi sakèjhâng[3], sakèjhâng dhâddhi satondun which means orèng rajâ asalla dâri kènè'[3] or if translated is "big people come from small people".

Always remembering where we came from is a good thought because we will not be arrogant and always like rice, the more it is filled with ducking. If we remember that we come from small people, we will not be arrogant people and we will not insult small people. In addition, we will always be grateful for the blessings that Allah has given us and will try to become a better person.

Big people come from small people, people who always remind us not to become kings or arrogant and arrogant. Par Liberation saarèp dhâddhi sakèjhâng, sakèjhâng dhâddhi satondun[3] always reminds us to always be aware of our shortcomings because we come from small people. We have many shortcomings both in terms of science, aspects of worship, and various other aspects.

You can't be a nut that forgets its shell. We must know what we have to do to become a better person because from remembering that freedom we will always and always be a person who is pleasant not only for ourselves but also a person who is pleasant to others around us.

Imitating par Freedoms saarèp dhâddhi sakèjhâng, sakèjhâng dhâddhi satondun[3], will also keep us getting results, but we will not forget the origin as in parébhâsan asèl ta 'adhina origin, bânnya' asèlla, tape ta 'loppa dâ' asalla[3] which if translated in Indonesian is "A lot of getting results (profits) but not forgetting the origin". There is no result that betrays effort, these words also have a somewhat similarity with the original par Liberation asèl ta 'adhina, that is, if we want a good result, of course everything comes from our efforts and hard work.

Maximum effort will bring us maximum results as well. Even though we will meet with failures in our struggle to obtain maximum results, we will still find satisfaction in our hearts as long as we have tried our best to what we can. We also will never stop trying and try again our best to get what we want.

\subsection{Ethical Values in Madurese Culture}

Mara ajâm kobhiriyân or orèng lakè 'sè ta' lotè' [3] or if translated into Indonesian is a very simple man, one of the par Liberations that can reflect a Madurese man. This parébhâsan reveals the simplicity of the Madurese man. simplicity will lead us to simplicity. Simple also will not make us an unattractive person, on the contrary, with simplicity we will be a more attractive and fun person because of course from that simplicity we will not become arrogant people.

Simple can also be said that he doesn't want much. Think a little simple in order to be able to be a good person and be able to think broadly. Many people are successful because they start from simplicity. Simple will make us a person who is smart, grateful and always humble.

Simple men certainly will not behave strangely and always behave naturally. Simple is one of the attitudes that need to be imitated so that we can all become individuals who are always in accordance with the portion and not exaggerating. A simple person, of course, must also have a refined attitude and not have a harsh attitude like parebas alos serraddhâ (fine fiber) which means bhângsa alos ta 'tao alako[3] coarse which if translated into Indonesian is a person who behaves subtly and cannot be rude.

People who are refined and can't be rude, maybe some people will judge that this person is weak, but 
in reality this kind of person is a really good person. Know where he should be and promote a sense of solidarity with others. A person who is refined and never being rude also means having no enemies and likes calm and peace in life.

Parébhâsan "alos serraddhâ" [3] is a good proverb and deserves to be followed so that we always have a calm attitude, friendly personality, and uphold a sense of comfort and peace. We must not jâmngajâmè (nas-manasè orèng sopajâ bângal alabân[3]) or if it is translated into Indonesian, the meaning is to provoke people to dare to fight.

An attitude of heating up people is something that should not be imitated because besides being not a good thing, such an attitude will also cause a lot of harm. Many new problems will arise if someone has an attitude like this. One of them is quarrels which might later on to eat innocent victims. You will also feel less comfortable, safe, and peaceful if one person causes chaos. We should have a good attitude so that the brotherhood between people can also be closer together.

\section{CONCLUSION}

Based on the studies or studies that have been described in the previous chapter, it can be concluded as follows: The form of religious values in Madurese culture in Madurese culture includes helping each other, respecting leaders, scholars, and kyai, being humble and always aware of inability, obeying people old, kind and always helps others, patient, does not commit disgraceful deeds, and is always grateful for the blessings of Allah.

The form of philosophical values in Madurese culture in Madurese freedom includes always finding a way out in all circumstances, never forgetting where we came from, always remembering that effort will bring results, work hard, cooperate with others, respect others, uphold self-esteem, brave, not easy to give up, lots of experiences that are not easily defeated, seek knowledge, have high aspirations, are fair and wise, and easy to adapt.

Forms of ethical values in Madurese culture in Madurese freedom include always being a simple person, being calm, a friendly person, and upholding a sense of comfort and peace, and always remembering that bad attitudes such as inciting other people to fight must be avoided. and should not be done, always reflect with oneself, do not harm others, do not stab from behind, are not ignorant, respect others, be kind to others, help others and accept other people's advice.
The study of oral literature such as Parébhâsan Madura cannot be separated from the life of the community where the literary work was born. Literary works, both oral and written, will always take pictures, describe, and even strip aesthetically the problems that occur in a society where the literary work was born. Thus the study of Parébhâsan Madura seeks to raise the values of socio-cultural life in the past, present, and maybe even in the future.

This study shows religious values, philosophical values, and ethical values, both local and universal. These values can be used as material for reflection, study, analysis, and even self-reflection for the Madurese people who live in the current digital era. This study is the first to discuss literary relations with Madurese society. Students and experts from various disciplines who want to understand the humanities of the Madurese community can benefit from this paper. This article presents a complete picture of the Madurese, that the Madurese are not like those described by researchers from outside Madura who only describe the negative side of Madurese life. The presence of Madurese literary works, both oral and written (read: Parébhâsan Madura) will guard the human struggle in an effort to dignify their humanity.

\section{REFERENCES}

[1] Sadik A S, 2005 Budaya Lokal Mempertegas Karakter Daerah Pamekasan.

[2] Rifai M A, 2007 Manusia Madura: Pembawaan, Perilaku, Etos Kerja, Penampilan, dan Pandangan Hidupnya seperti Dicitrakan Peribahasanya .

[3] Sastrodiwirjo O, 2013 Parebasan Ban Saloka Madura (Madura- Indonesia) Bandung: Kencana Utama.

[4] Busri H, 2010 Simbol Budaya Madura dalam Cerita Rakyat Madura Malang: Universitas Negeri Malang.

[5] Yasin M F, 2004 Representasi Pandangan Hidup Masyarakat Madura dalam Sastra Madura Modern Malang.

[6] Supratman M T, 2019 Humanitas Madura Solo: Oase Group.

[7] Miles, Mathew B. dan Huberman A M, 1992 Analisis Data Kualitatif: Buku Sumber Tentang Metode-Metode Baru Jakarta: Penerbit Universitas Indonesia. 